\title{
PERBEDAAN PERSEPSI TENTANG ETIKA BISNIS PADA MAHASISWA YANG BELUM DAN SUDAH MEMPELAJARI MATA KULIAH ETIKA BISNIS PADA PRODI AKUNTASI DI PERGURUAN TINGGI KOTA BATAM
}

\author{
Dinda Anastasyah ${ }^{1)}$, Hajan Hidayat ${ }^{2)}$ \\ 1) JurusanManajemen Bisnis,Politeknik Negeri Batam, Batam 29461, email: hajan@ polibatam.ac.id \\ 2) Jurusan Manajemen Bisnis,Politeknik Negeri Batam, Batam 29461, email: \\ dindatasyah12@gmail.com
}

\begin{abstract}
Abstrak
Etika bisnis merupakan pengetahuan tentang tata cara ideal pengaturan dan pengelolaan bisnis yang memperhatikan norma dan moralitas yang berlaku secara universal dan secara ekonomi atau sosial. Penerapan norma dan moralitas ini menunjang maksud dan tujuan kegiatan dalam bisnis. Penelitian ini bertujuan untuk mengetahui apakah terdapat perbedaan persepsi tentang etika bisnis antara mahasiswa yang belum dan sudah mempelajari mata kuliah etika bisnis prodi akuntansi pada perguruan tinggi di kota Batam. Sampel pada penelitian ini adalah 185 mahasiswa kelas reguler pagi prodi akuntansi pada perguruan tinggi terakreditasi di kota Batam. Pengujian hipotesis dalam penelitian ini menggunakan alat uji statistik Independent sampel T-Test yang terdapat pada SPSS 22.0 dan hasilnya menunjukkan bahwa terdapat perbedaan persepsi tentang etika bisnis antara mahasiswa yang belum dan sudah mempelajari mata kuliah etika bisnis. Penelitian ini menunjukkan bahwa pendidikan etika bisnis mempengaruhi persepsi mahasiswa sehingga mahasiswa yang sudah mengikuti mata kuliah etika bisnis mempunyai persepsi berbeda dengan mahasiswa yang belum mengikuti mata kuliah etika bisnis. Keterbatasan dalam penelitian ini adalah sampel yang digunakan hanya mahasiswa program studi akuntansi di Batam saja. Pendidikan etika bisnis sangat penting untuk menjadi bekal bagi mahasiswa dan harus lebih dimaksimalkan kurikulumnya. Saran untuk penelitian selanjutnya sebaiknya sampel yang diteliti diperluas, seperti dengan menggunakan mahasiswa program studi akuntansi yang ada di Kepulauan Riau dan juga menambah variable-variabel lain dalam penelitian.
\end{abstract}

Kata kunci: etika bisnis, persepsi tentang etika bisnis

\begin{abstract}
Business ethics is the knowledge about the procedures for setting up and managing ideal business into consideration the norms and morality universally applicable and economically or socially. The application of these norms and morality support the purpose and goals in business activities. This study aims to determine whether there are differences between the perceptions of business ethics and students who have already studied the subjects of business ethics in the accounting department of a university in the city of Batam. Samples are 185 regular grade student accounting Prodi morning at an accredited university in the city of Batam. Testing the hypothesis in this study using a statistical test Independent sample T-test contained in SPSS 22.0 and the results show that there are differences between the perceptions of business ethics and students who have already studied the subjects of business ethics. This study shows that business ethics education affects the perception of students so that students who have followed the course of business ethics have a different perception of students who have not followed the course of business ethics. Limitations of this study is the sample used only students of accounting in Batam alone. Business ethics education is very important to be a provision for students and should be maximized curriculum. Suggestions for further research should be expanded samples studied, such as using student of accounting in Riau Islands and also add other variables in the study.
\end{abstract}

Keywords: business ethics, perception toward business ethic 


\section{Pendahuluan}

Menghadapi MEA negara-negara ASEAN harus mempersiapkan sumber daya manusia (SDM) yang trampil, cerdas, dan kompetitif sebagai calon tenaga kerja. Tidak semua calon tenaga kerja bisa mendapatkan pekerjaan yang sesuai dengan keinginannya. Hanya mereka yang siap, yang mempunyai sikap profesional, dan bekal yang memadai yang bisa bersaing pada dunia kerja saat ini dan masa yang akan datang.

Profesional tidak hanya didasarkan pada keahlian seorang individu saja tapi mencakup bagaimana ia bisa berperilaku sesuai dengan standar moral dan etika. Menurut Ifada dan Ja'far (2005), Profesionalisme secara umum dapat dikatakan sebagai tanggung jawab individu untuk berperilaku yang lebih baik dari sekedar mematuhi undang-undang dan peraturan masyarakat yang ada. Profesionalisme merupakan elemen dari motivasi yang memberikan sumbangan pada seseorang agar mempunyai kinerja tugas yang tinggi. Etika merupakan seperangkat aturan, norma atau pedoman yang mengatur perilaku manusia, baik yang harus dilakukan maupun yang harus ditinggalkan yang dianut oleh sekelompok atau segolongan masyarakat atau profesi (Maryani dan Tikollah, 2006).

Menurut Juliarta et al., (2015) etika dalam perkembangannya sangat mempengaruhi kebutuhan manusia. Etika memberi manusia orientasi bagaimana ia menjalani hidupnya melalui rangkaian tindakan sehari-hari. Itu berarti etika membantu manusia untuk mengambil sikap dan tindakan secara tepat dalam menjalankan hidup ini. Etika pada akhirnya membantu kita untuk mengambil keputusan tentang tindakan apa yang perlu kita lakukan dan yang perlu kita pahami bersama bahwa etika ini dapat diterapkan dalam segala aspek atau sisi kehidupan kita. Dapat disimpulkan bahwa etika dalam suatu pekerjaan akan membentuk sikap etis seorang professional.

Etika bisnis merupakan pengetahuan tentang tata cara ideal pengaturan dan pengelolaan bisnis yang memperhatikan norma dan moralitas yang berlaku secara universal dan secara ekonomi atau sosial. Penerapan norma dan moralitas ini menunjang maksud dan tujuan kegiatan dalam bisnis. Dalam penerapan etika bisnis, maka bisnis mesti mempertimbangkan unsur norma dan moralitas yang berlaku di dalam masyarakat. Di samping itu etika bisnis dapat digerakkan dan dimunculkan dalam perusahaan sendiri karena memiliki relevansi yang kuat dengan profesionalisme bisnis (Untung, 2012).

Contoh pelanggaran etika bisnis yang dilakukan oleh perusahaan yaitu PT KAI yang melakukan manipulasi laporan keuangan pada tahun 2006 (Prabowo, 2006). PT Megarsari Makmur tahun 2006 melakukan pelanggaran etika bisnis dengan melakukan penggunaan zat aktif yang dapat mengakibatkan gangguan kesehatan. Zat tersebut digunakan dalam produk HIT sebagai obat anti nyamuk (Muchamad, 2006). Pada tahun 2006 perusahaan PJTKI yang melanggar prinsip pertanggungjawaban melakukan penipuan kepada para calon TKI dengan menjanjikan keberangkatan namun tidak kunjung direalisasikan (Hardum, 2014).

Institusi pendidikan menyelenggarakan pendidikan etika bisnis dengan tujuan untuk mengurangi dan mencegah pelanggaran etika bisnis. Pendidikan etika bisnis dianggap efektif dalam meningkatkan sikap yang beretika. Penelitian Al-shaikh et al., (2012) menyimpulkan bahwa responden laki-laki dan perempuan berbeda dalam sikap mereka terhadap etika bisnis, namun dengan adanya pendidikan etika bisnis di kurikulum pendidikan yang menekankan pentingnya berperilaku etis dengan orang tua, keluarga dan masyarakat membuat laki-laki dan perempuan tidak memiliki perbedaan yang signifikan dalam hal sikap mereka terhadap etika bisnis.

Penelitian Sari (2009) menyimpulkan bahwa ada pengaruh pemberian muatan etika dalam pendidikan akuntansi dengan persepsi etika mahasiswa yang diproksikan dengan pemahaman akuntansi keuangan dan etika dalam sebuah profesi. Mengacu pada penelitian persepsi mahasiswa berdasarkan perbedaan demografi siswa dan karakteristik profesional, yang dilakukan Al-shaikh et al., (2012) dan penelitian Sari (2009) yang mengacu pada pemberian muatan etika. Perbedaan penelitian ini dengan penelitian sebelumnya adalah peneliti tidak memasukkan mahasiswa kelas karyawan atau mahasiswa yang sudah bekerja seperti penelitian sebelumnya dengan maksud agar dapat melihat apakah pendidikan etika bisnis yang selama ini diajarkan kepada mahasiswa sudah efektif atau belum sehingga terlihat ada perbedaan antara mahasiswa yang belum dan sudah mendapat pendidikan etika bisnis atau justru sebaliknya tidak terdapat perbedaan.

\section{Landasan Teori dan Pengembangan Hipotesis}

\section{Persepsi}

Menurut Slameto (2010) persepsi dimulai dengan masuknya pesan atau informasi kedalam otak manusia, melalui persepsi manusia terus menerus mengadakan hubungan dengan lingkungannya. Hubungan ini dilakukan lewat inderanya, yaitu indera pengelihat, pendengar, peraba, perasa, dan pencium. 
Menurut Philip (1993) persepsi adalah proses bagaimana seseorang menyeleksi, mengatur masukanmasukan informasi untuk menciptakan gambaran keseluruhan yang berarti. Persepsi merupakan suatu proses kategorisasi dan interpretasi yang bersifat selektif. Adapun faktor yang mempengaruhi persepsi seseorang adalah katakteristik orang yang dipersepsi dan faktor situasional.

Menurut Vincent (1997) Faktor-faktor yang mempengaruhi persepsi:

1. Pengalaman masa lalu bisa mempengaruhi seseorang karena manusia biasanya akan menarik kesimpulan yang sama dengan apa yang ia lihat, dengar, dan rasakan pada masa lalu yang berpengaruh dengan masa sekarang.

2. Keinginan dapat mempengaruhi persepsi seseorang dalam hal membuat keputusan. Manusia cenderung menolak tawaran yang tidak sesuai dengan apa yang ia harapkan dan memilih apa yang menjadi harapannya.

3. Pengalaman dari teman-teman, dimana mereka akan menceritakan pengalaman yang telah dialaminya. Hal ini jelas mempengaruhi persepsi seseorang, karena seseorag akan mempunyai percaya yang lebih kepada temen-temannya sehingga apa yang diceritakan oleh temannya dianggap benar.

\section{Etika Bisnis}

Menurut Hill dan Jones (1998) setiap pelaksanaan bisnis harus menyelaraskan proses bisnis tersebut dengan etika bisnis yang telah disepakati secara umum dalam lingkungan tersebut. Etika bisnis merupakan ajaran untuk membedakan mana yang salah dan mana yang benaruntuk memberikan pembekalan kepada setiap pemimpin perusahaan ketika mempertimbangkan untuk mengambil keputusan.

Menurut Yosephus (2010) etika bisnis secara hakiki merupakan etika terapan. Etika bisnis merupakan wilayah penerapan prinsip-prinsip moral umum pada wilayah tindak manusia di bidang ekonomi, khususnya bisnis. Jadi, secara hakiki sasaran etika bisnis adalah perilaku moral pebisnis yang berkegiatan ekonomi.

Menurut Embse dan Wagley (1988) terdapat tiga pendekatan dasar dalam merumuskan tingkah laku etika bisnis, yaitu:

1. Utilitarian Approach: Konsep etika yang menyatakan bahwa perilaku-perilaku moral harus menghasilkan kebaikan terbesar bagi kelompok mayoritas. Dengan pendekatan ini, seorang pengambil keputusan diharapkan untuk mempertimbangkan akibat dari setiap alternatif yang diambil terhadap semua pihak. Dalam bertindak seseorang seharusnya mengikuti cara- cara yang dapat memberi manfaat sebesarbesarnya kepada masyarakat, dengan cara yang tidak membahayakan dan dengan biaya serendah-rendahnya.

2. Individual Rights Approach: Konsep etika yang menyatakan suatu tindakan adalah normal jika mendukung kepentingan jangka panjang individu yang akhirnya mengarah kepada kebaikan yang lebih besar. Para individu menghitung manfaat jangka panjang terbaik yang mereka peroleh sebagai ukuran dari keberhasilan sebuah keputusan. Setiap orang dalam tindakan dan kelakuannya memiliki hak dasar yang harus dihormati.

3. Justice Approach: Konsep etika yang memandang bahwa keputusan-keputusan moral adalah keputusan yang tidak melanggar hak sosial dari mereka yang dipengaruhi oleh keputusan tersebut. Maka keputusan benar secara etika jika keputusan tidak melanggar hak asasi dari mereka yang kena dampak keputusan itu. Para pembuat keputusan mempunyai kedudukan yang sama, dan bertindak adil dalam memberikan pelayanan .

Menurut Keraf (1998) prinsip etika bisnis terdiri dari:

1. Prinsip Otonomi, sikap manusia untuk mengambil keputusan dan bertindak berdasarkan kesadarannya tentang apa yang dianggapnya baik untuk dilakukan dan tidak melakukan tindakan yang buruk. Orang yang mandiri berarti orang yang dapat mengambil suatu keputusan dan melaksanakan tindakan berdasarkan kemampuan sendiri sesuai dengan apa yang diyakininya, bebas dari tekanan, hasutan, dan ketergantungan kepada pihak lain. Oleh karena itu, syarat mutlak yang harus diciptakan untuk membentuk sikap mandiri adalah mengembangkan suasana kebebasan dalam berpikir dan bertindak. Namun harus disadari bahwa kebebasan dalam hal ini harus disertai dengan kesadaran akan pentingnya memupuk rasa tanggung jawab. Kebebasan tanpa rasa tanggung jawab akan memunculkan manusia pengecut dan munafik, sedangkan kebebasan disertai tanggung jawab akan menumbuhkan "sikap kesatria", yaitu sikap berani bertindak dan mengatakan hal yang benar sekaligus berani dan berjiwa besar mengakui suatu kesalahan, serta berani menanggung konsekuensinya.

Prinsip Kejujuran, bisnis tidak akan bisa bertahan lama dan berhasil kalau tidak didasarkan atas kejujuran. 
Baik jujur dalam pemenuhan syarat-syarat perjanjian dan kontrak, jujur dalam penawaran barang atau jasa dengan mutu dan harga yang sebanding, dan jujur dalam hubungan kerja intern dalam suatu perusahaan. Prinsip kejujuran menjadi persyaratan untuk membangun jaringan bisnis dan kerja tim yang dilandasi oleh rasa saling percaya dengan semua mitra usaha dan mitra kerja.

2. Prinsip Keadilan, menanamkan sikap untuk memperlakukan semua pihak secara adil (fair), yaitu suatu sikap yang tidak membeda-bedakan dari berbagi aspek, baik dari aspek ekonomi (menyangkut distribusi pendapatan), aspek hukum (dalam hal perlakuan yang sama di mata hukum), maupun aspek lainnya seperti: agama, ras, suku, dan jenis kelamin. Setiap orang harus diperlakukan adil sesuai kriteria yang rasional obyektif, serta dapat dipertanggung jawabkan.

3. Prinsip Saling Menguntungkan (Mutual Benefit Principle), menanamkan kesadaran bahwa berbisnis perlu ditanamkan prinsip win-win solution, artinya dalam setiap keputusan dan tindakan bisnis harus diusahakan agar semua pihak merasa diuntungkan. Prinsip ini melandasi lahirnya konsep stakeholders dalam proses keputusan dan tindakan bisnis.

4. Prinsip Integritas Moral, prinsip untuk tidak merugikan orang lain dalam segala keputusan dan tindakan bisnis yang diambil. Prinsip ini dilandasi oleh kesadaran bahwa setiap orang harus dihormati harkat dan martabatnya.

Menurut Embse dan Wagley (1988) etika bisnis dalam perusahaan memiliki peran yang sangat penting, yaitu agar perusahaan mempunyai kemampuan menciptakan nilai (value-creation) yang tinggi, suatu landasan yang kokoh untuk membentuk suatu perusahaan yang kuat dan memiliki daya saing yang tinggi.

Menurut Keraf (1998) dalam menciptakan etika bisnis ada beberapa hal yang perlu diperhatikan, antara lain:

\section{Pengendalian Diri}

Pengendalian diri dimana pelaku-pelaku bisnis dan pihak yang terkait mampu mengendalikan diri mereka masing-masing untuk tidak memperoleh apapun dari siapapun dan dalam bentuk apapun dan pelaku bisnis sendiri tidak mendapatkan keuntungan dengan jalan main curang serta penggunaannya juga harus memperhatikan kondisi masyarakat sekitarnya.

\section{Pengembangan Tanggung Jawab Sosial (Social} Responsibility)
Perusahaan perlu dijalankan dengan tetap bersikap tanggap, peduli, dan bertanggung jawab atas hak dan kepetingan banyak pihak lainnya,termasuk di dalamnya lingkungan sekitar atau masyarakat sekitar.Tanggung jawab sosial perusahaan sesungguhnya mengacu pada kenyataan bahwa perusahaan tidak bisa hidup, beroperasi, dan memperoleh keuntungan bisnis tanpa pihak.

\section{Pendidikan Etika Bisnis}

Menurut Gaa dan Thorne (2004) etika bisnis merupakan mata kuliah yang diajarkan di lingkungan pendidikan tinggi yang menawarkan program pendidikan bisnis dan manajemen. Pendidikan akuntansi selama ini memfokuskan pada dimensi pilihan kebijakan tetapi tidak memperhatikan nilai dan kredibilitas yang mempengaruhi pilihan tersebut.

Menurut pasal 1 UU RI No. 22 tahun 1961, pengertian perguruan tinggi adalah lembaga ilmiah yang mempunyai tugas menyelenggarakan pendidikan dan pengajaran di atas perguruan tingkat menengah, dan yang memberikan pendidikan dan pengajaran berdasarkan kebudayaan kebangsaan Indonesia dan dengan cara ilmiah. Dapat diartikan juga bahwa perguruan tinggi atau universitas merupakan sebuah lembaga pendidikan perguruan tinggi dan penelitian, yang memberikan gelar akademik dalam berbagai bidang ilmu pengetahuan seperti ilmu ekonomi, filsafat, hukum, pemerintahan, ilmu eksakta, kedokteran dan lain sebagainya. Perguruan tinggi atau yang lebih dikenal dengan istilah universitas memiliki beberapa tujuan yang digunakan sebagai salah satu pedoman mendasar dalam program pelaksanaan pendidikan. Tujuan perguruan tinggi atau universitas menurut pasal 22 UU RI No. 22 tahun 1961 yaitu sebagai berikut:

1. Membentuk manusia susila yang berjiwa Pancasila dan bertanggung-jawab akan terwujudnya masyarakat sosialis Indonesia yang adil dan makmur, materiil dan spiritual.

2. Menyiapkan tenaga yang cakap untuk memangku jabatan yang memerlukan pendidikan tinggi dan yang cakap berdiri sendiri dalam memelihara dan memajukan ilmu pengetahuan.

3. Melakukan penelitian dan usaha kemajuan dalam lapangan ilmu pengetahuan, kebudayaan dan kehidupan kemasyarakatan.

Menurut Loeb (1992) pada saat ini pengintegrasian etika ke dalam program akuntansi pada perguruan tinggi masih dalam taraf minimum, dan merekomendasikan perlunya peningkatan program etika dalam akuntansi. 
Tujuan pendidikan etika bisnis adalah agar mahasiswa memiliki pengetahuan dan pemahaman tentang konsep-konsep dasar etika bisnis dan agar mahasiswa mampu menerapkan etika bisnis dalam situasi sesungguhnya. Materi pendidikan etika bisnis antara lain:

1. Kode etik profesi akuntan.

2. Etika dilingkungan kerja dan sosial.

3. Prinsip-prinsip etika bisnis.

Pendekatan dasar dalam merumuskan tingkah laku etika bisnis yaitu etika yang menyatakan bahwa perilaku-perilaku moral harus menghasilkan kebaikan terbesar bagi kelompok mayoritas dan tindakan dikatakan normal jika mendukung kepentingan jangka panjang individu yang akhirnya mengarah kepada kebaikan yang lebih besar serta keputusan yang dibuat tidak melanggar hak sosial dari mereka yang dipengaruhi oleh keputusan tersebut. Etika bisnis mempunyai prinsip bahwa sikap manusia untuk mengambil keputusan dan bertindak berdasarkan kesadarannya tentang apa yang dianggapnya baik untuk dilakukan dan tidak melakukan tindakan yang buruk. Selain itu, prinsip kejujuran menjadi persyaratan untuk membangun jaringan bisnis dan kerja tim yang dilandasi oleh rasa saling percaya dengan semua mitra usaha dan mitra kerja serta menanamkan sikap untuk memperlakukan semua pihak secara adil. Prinsip etika bisnis lain yaitu menanamkan kesadaran bahwa berbisnis perlu ditanamkan prinsip win-win solution, artinya dalam setiap keputusan dan tindakan bisnis harus diusahakan agar semua pihak merasa diuntungkan dan kesadaran bahwa setiap orang harus dihormati harkat dan martabatnya.

Akman (2011) di Turkei menyimpulkan bahwa pekerjaan, sektor, jenis kelamin, dan usia berkorelasi positif dengan persepsi etika bisnis dan tidak ada korelasi signifkan yang ditemukan antara pendidikan. Al-shaikh et al., (2012) menyimpulkan bahwa responden laki-laki dan perempuan berbeda dalam sikap mereka terhadap etika bisnis, namun dengan adanya pendidikan etika bisnis pada kurikulum bangku kuliah dengan menekankan pentingnya berperilaku etis dengan orang tua keluarga, masyarakat dan kemudian dalam praktek bisnis yang mengakibatkan ketika memasuki tenaga kerja, lakilaki dan perempuan tidak memiliki perbedaan yang signifikan dalam hal sikap mereka terhadap etika bisnis.

Silanont (2012) menunjukkan bahwa peserta yang memiliki pelatihan etika di tempat kerja akan memiliki perilaku yang lebih etis. Penelitian Svanberg (2013) yang meneliti persepsi karyawan pada etika bisnis di organisasi menemukan bahwa tidak ada hubungan signifikan antara persepsi karyawan tentang etika bisnis dan usia mereka di organisasi serta jenis kelamin mereka. Maulina (2011) menemukan bahwa ada perbedaan yang signifikan antara persepsi mahasiswa akuntansi perguruan tinggi negeri dengan mahasiswa akuntansi perguruan tinggi swasta terhadap muatan etika bisnis dan profesi dalam kurikulum akuntansi. Penelitian Pratomowati (2012) menemukan bahwa terdapat perbedaan persepsi etika antara mahasiswa Fakultas ekonomi bisnis dengan Fakultas ilmu budaya. Penelitian Martadi dan Suranta (2006) menemukan bahwa tidak terdapat perbedaan persepsi yang signifikan antara akuntan pria, akuntan wanita, mahasiswa akuntansi, mahasiswi akuntansi, dan karyawan bagian akuntansi terhadap etika bisnis.

Mubarok et al., (2010) menunjukkan perbedaan persepsi tentang etika bisnis antara mahasiswa yang belum bekerja dan mahasiswa yang sudah pernah bekerja secara statistik tidak signifikan. Praktik kerja yang dihadapi juga tidak mempengaruhi persepsi tentang etika bisnis. Penelitian suradi et al., (2010) menemukan bahwa persepsi integritas moral, kompetensi, tanggung jawab, kejujuran dan keadilan secara simultan berpengaruh terhadap etika bisnis dan etika akuntan pada mahasiswa program studi Akuntansi di Perguruan tinggi Surakarta. Penelitian Charismawati (2011) menemukan bahwa terdapat hubungan antara tingkat love of money pada mahasiswa akuntansi dengan persepsi etis dan jenis kelamin tidak mempengaruhi tingkat love of money pada mahasiswa namun berpengaruh terhadap tingkat persepsi etis mahasiswa.

Pendidikan yang berkualitas merupakan bagian dari kebutuhan peningkatan sumber daya manusia pada masa mendatang. Warna yang diberikan oleh dunia pendidikan akan ikut mewarnai perilaku masyarakat. Oleh karena itu pembangunan dunia pendidikan yang etis dan bermoral menjadi sangat penting dalam rangka membentuk masyarakat yang madani (Utami, 2005). Pendidikan etika bisnis mengajarkan pengetahuan apa itu etika, bagaimana beretika yang baik di tempat kerja, seperti apa norma-norma dalam dunia kerja, apa yang termasuk pelanggaran etika bisnis, dan ini akan mempengaruhi pola pikir mahasiswa itu sendiri serta menumbuhkan kesadaran etis dan perilaku etis melalui apa yang mereka serap pada pembelajaran etika bisnis tersebut.

Memasukkan aspek etika langsung pada mata kuliah akuntansi akan sangat membantu mahasiswa untuk mempertajam moral perception dan moral judgement dari topik-topik yang dibahas. Banyak contoh kasus etika yang disajikan dalam text book dapat digunakan sebagai bahan diskusi, di samping itu juga dibahas kasus dalam konteks Indonesia (Sari, 2012).

Penelitian mengenai pendidikan etika bisnis pada mahasiswa masih memberikan hasil yang berbeda. Akman (2011) di Turkey menyimpulkan bahwa pekerjaan, sektor, jenis kelamin, dan usia berkorelasi positif dengan persepsi etika bisnis dan tidak ada korelasi signifkan yang ditemukan antara pendidikan. 
Al-shaikh et al., (2012) menyimpulkan bahwa responden laki-laki dan perempuan berbeda dalam sikap mereka terhadap etika bisnis, namun dengan adanya pendidikan etika bisnis pada kurikulum bangku kuliah dengan menekankan pentingnya berperilaku etis dengan orang tua keluarga, masyarakat dan kemudian dalam praktek bisnis yang mengakibatkan ketika memasuki tenaga kerja, lakilaki dan perempuan tidak memiliki perbedaan yang signifikan dalam hal sikap mereka terhadap etika bisnis.

Silanont (2012) menunjukkan bahwa peserta yang memiliki pelatihan etika di tempat kerja akan memiliki perilaku yang lebih etis. Penelitian Svanberg (2013) yang meneliti persepsi karyawan pada etika bisnis di organisasi menemukan bahwa tidak ada hubungan signifikan antara persepsi karyawan tentang etika bisnis dan usia mereka di organisasi serta jenis kelamin mereka. Maulina (2011) menemukan bahwa ada perbedaan yang signifikan antara persepsi mahasiswa akuntansi perguruan tinggi negeri dengan mahasiswa akuntansi perguruan tinggi swasta terhadap muatan etika bisnis dan profesi dalam kurikulum akuntansi. Penelitian Pratomowati (2012) menemukan bahwa terdapat perbedaan persepsi etika antara mahasiswa Fakultas ekonomi bisnis dengan Fakultas ilmu budaya. Penelitian Suranta (2006) menemukan bahwa tidak terdapat perbedaan persepsi yang signifikan antara akuntan pria, mahasiswa akuntansi, akuntan wanita, mahasiswi akuntansi, dan karyawan bagian akuntansi terhadap etika bisnis.

Mubarok et al., (2010) menunjukkan perbedaan persepsi tentang etika bisnis antara mahasiswa yang belum bekerja dan mahasiswa yang sudah pernah bekerja secara statistik tidak signifikan. Praktik kerja yang dihadapi juga tidak mempengaruhi persepsi tentang etika bisnis. Penelitian suradi et al., (2010) menemukan bahwa persepsi integritas moral, kompetensi, tanggung jawab, kejujuran dan keadilan secara simultan berpengaruh terhadap etika bisnis dan etika akuntan pada mahasiswa program studi Akuntansi di Perguruan tinggi Surakarta. Penelitian Charismawati (2011) menemukan bahwa terdapat hubungan antara tingkat love of money pada mahasiswa akuntansi dengan persepsi etis dan jenis kelamin tidak mempengaruhi tingkat love of money pada mahasiswa namun berpengaruh terhadap tingkat persepsi etis mahasiswa.

Pendidikan etika akan mempengaruhi persepsi etika bisnis seorang mahasiswa, karena apa yang dia pelajari dalam kurikulum etika bisnis akan mempengaruhi pengetahuan dan juga pola pikir mahasiswa tentang bagaimana etika bisnis yang seharusnya, bagaimana bersikap dalam dunia kerja, apa saja yang baik dan buruk dalam beretika, bagaimana mengambil keputusan yang tepat dengan mempertimbangkan lingkungan dan sebagainya. Karena itu diperkirakan adanya perbedaan antara mahasiswa yang belum mendapat pembelajaran etika bisnis dengan mahasiswa yang sudah mendapat pembelajaran etika bisnis sehingga hipotesis dalam penelitian ini adalah:

H1: terdapat perbedaan persepsi etika bisnis antara mahasiswa yang sudah mendapat pembelajaran etika bisnis dengan mahasiswa yang belum mendapat pembelajaran etika bisnis.

\section{Metode Penelitian}

\section{Jenis dan Sumber Data}

Pada penelitian ini penulis menggunakan penelitian kuantitatif, karena data yang diperoleh nantinya berupa angka. Dari angka yang diperoleh akan dianalisis lebih lanjut dalam analisis data dan penulis menggunakan data primer berupa data dari kuesioner yang dibagikan kepada mahasiswa program studi akuntansi perguruan tinggi di Batam. Peneliti menggunakan data interval dengan metode penskalaan untuk instrument yang digunakan adalah skala ratih yaitu skala likert (Likert scale).

\section{Lokasi dan Objek Penelitian}

Penelitian dilakukan di Perguruan tinggi terakreditasi di Batam yang mempunyai program studi akuntansi. Obyek penelitian yaitu mahasiswa program studi akuntansi kelas reguler siang yang terdaftar sebagai mahasiswa aktif untuk tahun ajaran 2015/ 2016. Mahasiswa yang diteliti adalah mereka yang belum mendapat pembelajaran etika bisnis dan yang sudah mendapat pelajaran etika bisnis.

\section{Teknik Penarikan Sampel}

Pada penelitian ini teknik penarikan sampel yang digunakan adalah pengambilan secara bukan random (acak) atau non probability sampling. Teknik ini menarik sampel dengan kriteria atau penilaian tertentu. Kriteria dipilih berdasarkan pertimbangan (judgment) yaitu dimaksudkan agar kriteria sampel yang dipilih benar-benar sesuai dengan penelitian yang akan dilakukan. Sampel penelitian yaitu mahasiswa jurusan akuntansi yang belum mendapat pembelajaran etika bisnis dan mereka yang sudah mendapat pembelajaran etika bisnis kelas regular pagi saja.

\section{Teknik Pengolahan Data}

Pada penelitian ini penulis menggunakan data primer yang diperoleh dari kusioner yang disebarkan kepada responden. Prosedur penelitian data yang dilakukan dalam penelitian ini adalah menentukan variabelvariabel yang akan dimasukkan dalam tabel frekuensi. 
Selanjutnya tahap editing yaitu dengan membaca kembali data yang telah terkumpul melalui kuesioner, untuk melihat apakah ada hal-hal yang meragukan dalam pengisian kuesioner dengan tujuan memperbaiki kualitas data. Tahap coding juga perlu dilakukan yaitu dengan member kode pada data data terkait jawaban dari reponden untuk mempermudah peneliti dalam menganalisis data serta tahap tabulasi yaitu untuk menyajikan datadata yang diperoleh ke dalam tabel (Hartono, 2004). Data yang diperoleh dijadikan sampel ke dalam Microsoft Office Excel 2010. Data yang telah ditabulasi ke dalam Microsoft Office Excel 2010 kemudian diolah dengan menggunakan alat pengolahan data SPSS.

\section{Hasil dan Pembahasan}

Pengujian hipotesis dengan menggunakan alat uji statistik Independent sampel T-Test untuk membuktikan adanya perbedaan persepsi mahasiswa yang sudah mendapat pembelajaran etika bisnis dan mahasiswa yang belum mendapat pembelajaran etika bisnis dapat dilihat pada tabel dibawah ini.

\begin{tabular}{|c|c|c|c|c|}
\hline MAHASISWA & $\mathrm{N}$ & Mean & $\mathrm{t}$ & $\begin{array}{l}\text { Sig.(2- } \\
\text { tailed) }\end{array}$ \\
\hline $\begin{array}{l}\text { Sudah } \\
\text { mendapat } \\
\text { pembelajaran } \\
\text { etika bisnis }\end{array}$ & 94 & 64.73 & & \\
\hline $\begin{array}{l}\text { Belum } \\
\text { mendapat } \\
\text { pembelajaran } \\
\text { etika bisnis }\end{array}$ & 91 & 59.20 & & \\
\hline $\begin{array}{l}\text { Equal variances } \\
\text { assumed }\end{array}$ & & & 7.591 & 0.000 \\
\hline
\end{tabular}

\section{Uji Independent Sample T-test}

Sumber: Pengolahan Data kuesioner SPSS 22.00

Hasil uji independent sample t-test dilihat dari tabel diatas menunjukkan rata-rata sampel mahasiswa yang sudah mendapat pembelajaran etika bisnis dan mahasiswa yang belum mendapat pembelajaran etika bisnis adalah 64.73 dan 59,20 serta standar devisiasi mahasiswa yang sudah mendapat pembelajaran etika bisnis 3,418 dan standar devisiasi mahasiswa yang belum mendapat pembelajaran etika bisnis 6,159. Hipotesis penelitian rata-rata persepsi mahasiswa yang sudah mendapat pembelajaran etika bisnis lebih besar dari pada dan mahasiswa yang belum mendapat pembelajaran etika bisnis. Pengambilan keputusan analisis dilihat dari perbandingan $\mathrm{t}$ hitung dan $\mathrm{t}$ tabel, apabila t hitung positif seperti yang terlihat di tabel 4.10 maka terdapat perbedaan bermakna (Ho ditolak) apabila $\mathrm{t}$ hitung $>\mathrm{t}$ tabel. Tabel distribusi $\mathrm{t}$ dicari pada $(\alpha) 5 \%: 2=2,5 \%$ (uji 2 sisi) dengan derajat kebebasan (df) n-2 atau $185-2=183$. Dengan pengujian dua sisi (signifikansi $=0,025$ ) hasil diperoleh untuk $\mathrm{t}$ tabel sebesar 1,9730 . Nilai $\mathrm{t}$ hitung > t tabel yaitu 7,591 > 1,973 maka terdapat perbedaan bermakna atau dengan kata lain H1 didukung.

Penelitian ini menunjukkan bahwa pendidikan etika bisnis mempengaruhi persepsi etika bisnis mahasiswa. Informasi-informasi tentang etika bisnis dan apa yang dia pelajari dalam kurikulum etika bisnis akan mempengaruhi pengetahuan serta pola pikir mahasiswa. Menurut Philip (1993) persepsi itu sendiri adalah proses seseorang menyeleksi, mengatur masukan-masukan informasi untuk menciptakan gambaran keseluruhan yang berarti. Persepsi merupakan suatu proses kategorisasi dan interpretasi yang bersifat selektif. Salah satu faktor yang mempengaruhi persepsi adalah faktor fisiologis yaitu informasi yang masuk melalui indera selanjutnya akan mempengaruhi dan melengkapi usaha untuk memberikan arti terhadap sesuatu.

Mata kuliah etika bisnis memuat materi tentang kode etik profesi akuntan, etika dilingkungan kerja dan sosial serta prinsip-prinsip etika bisnis, apa yang dipelajari dalam mata kuliah etika bisnis inilah yang mempengaruhi persepsi mahasiswa sehingga mahasiswa yang sudah mendapat pembelajaran etika bisnis lebih memahami etika bisnis itu sendiri serta apa yang mahasiswa pelajari dalam kurikulum etika bisnis akan mempengaruhi pengetahuan dan juga pola pikir mahasiswa tentang bagaimana etika bisnis seharusnya, bagaimana bersikap dalam dunia kerja, apa saja yang baik dan buruk dalam beretika, bagaimana mengambil keputusan yang tepat dengan mempertimbangkan mana yang benar dan salah dalam mengambil keputusan sesuai dengan ajaran etika bisnis itu sendiri seperti yang di ungkapkan oleh Hill dan Jones (1998) etika bisnis merupakan ajaran untuk membedakan mana yang salah dan mana yang benar untuk memberikan pembekalan kepada setiap pemimpin perusahaan ketika mempertimbangkan untuk mengambil keputusan.

\section{Simpulan}

Penelitian ini bertujuan menganalisis dan membuktikan secara empiris mengenai perbedaan persepsi mahasiswa program studi akuntansi di Batam yaitu antara mahasiswa yang belum mempelajari etika bisnis dan mahasiswa yang sudah mempelajari etika bisnis. Hasil dari penelitian ini menunjukkan bahwa terdapat perbedaan persepsi antara mahasiswa yang belum mempelajari etika bisnis dengan mahasiswa yang sudah mempelajari mata kuliah etika bisnis. 
Pengetahuan yang didapat dalam mata kuliah etika bisnis mempengaruhi persepsi mahasiswa. Persepsi itu sendiri dipengaruhi oleh informasi-informasi yang didapat seseorang, mahasiswa yang sudah mendapat pembelajaran etika bisnis akan mendapat informasiinformasi serta pengetahuan. Mahasiswa akan mendapat pengetahuan tentang bagaimana bersikap dalam dunia kerja, apa saja yang baik dan buruk dalam beretika, bagaimana mengambil keputusan yang tepat dengan mempertimbangkan mana yang benar dan salah dalam mengambil keputusan sesuai dengan ajaran etika bisnis sehingga mahasiswa yang sudah mendapat pembelajaran etika bisnis lebih memahami etika bisnis itu sendiri.

\section{Keterbatasan dan Saran}

Penelitian ini terdapat keterbatasan yaitu sampel yang digunakan tidak terlalu luas hanya mahasiswa program studi akuntansi di Batam saja.

Hasil penelitian ini menunjukkan ada perbedaan persepsi antara mahasiswa yang sudah mendapat pembelajaran etika binis dengan mahasiswa yang belum mendapat pembelajaran etika bisnis. Hal ini menunjukkan pendidikan etika bisnis sangat penting untuk menjadi bekal bagi mahasiswa dan harus lebih dimaksimalkan kurikulumnya. Pada dasarnya mahasiswa sudah mengetahui dasar etika bisnis itu sendiri, namun untuk lebih mempersiapkan sumber daya manusia yang lebih siap dimasa yang akan datang, maka pemberian materi lebih mendalam seputar etika bisnis dan juga pembelajaran tentang etika bisnis perlu. Hal ini perlu menjadi pertimbangan bagi perguruan tinggi dan pemerintah sehingga ke depannya masalah-masalah etika bisnis yang belakangan ini marak terjadi di Indonesia tidak terulang kembali di masa yang akan datang.

Saran untuk penelitian selanjutnya sebaiknya sampel yang diteliti diperluas, seperti dengan menggunakan mahasiswa program studi akuntansi yang ada di Kepulauan Riau dan juga menambah variabel-variabel lain dalam penelitian.

\section{Referensi}

[1] Agoes, S., \& Ardana, I. C. (2009). Etika Bisnis dan Profesi. Jakarta: Salemba Empat.

[2] Akman, V. (2011). Empirical Look at the Factors Affecting Perception of Business Ethics in Turkey. Boykent University.

[3] Ali. (2015, april 1). Pembahasan Mengenai Pengertian Etika Menurut Pakar. Retrieved januari 10, 2016, from Pengertian Etika MenurutPakar: http://www.pengertianpakar.com/2015/04/pengert ian-etika-menurut-pakar.html?m=1\#_'1

[4] Al-shaikh, F. N., Elian, M. I., \& Tahat, L. H. (2012). Business Studentds Attitudes towards Business Ethics: Evidence from Kuwait. Journal of International Conference on Business, Economics, and Behavioral Sciences.

[5] Bertens, K. (1999). Pengantar Etika Bisnis. Yogyakarta: Kanisius.

[6] Charismawati, C. (2011). Analisis Hubungan Antara Love of Money Dengan Persepsi Etika Mahasiswa Akutansi. Semarang: Perguruan tinggi Diponegoro.

[7] Embse, Von der \& Wagley, R.A.(1988). Managerial Ethics Hard Decisions on Soft Criteria. Journal of Advance Managemen.

[8] Emerson, M., Jones, K., Lancaster, L., \& Whilden, T. (2010). Undergraduate Ethics: A Comparative Analysis Of The Ethical Framework Of Business Students From Different Generations. Journal of Northwest Nazarene University.

[9] English, D., Manton, E., \& Walker, J. (2006). Have Business Communication Instructors changed their perception of business ? A Comparative Study. Journal of Organizational Culture, Communications and Conflict.

[10]Hardum, S. E. (2014, febuari 28). Berita satu. Retrieved 3 10, 2016, from Suara Pembaruan: http://www.beritasatu.com/hukum/168736-pjtkiharus-setorkan-deposito-minimal-rp-10miliar.html

[11]Hartono, J. (2004). Metedeologi Penelitian Bisnis. Yogyakarta: BPFE.

[12]Hill, Charles W.L., \& Jones Gareth R. (1998). Strategic management Theory: An Integrated Approach. Fourth Edition, Houghton Mifflin, Boston.

[13]Ifada \& M. Ja'far. (2005). Pengaruh Sikap Profesionalisme Internal Auditor terhadap Peranan Internal Auditor dalam Pengungkapan Temuan Audit.Jurnal Bisnis, Manajemen dan Ekonomi. Vol.7 No. 3

[14]Juliarta, G., Herawati, N. T., \& Sulindawati, N. G. (2015). Persepsi Mahasiswa Jurusan Akuntansi dan Akuntan Publik Terhadap Etika Bisnis dan Etika Profesi Akuntan. e-Journal S1 Ak Perguruan tinggi Pendidikan Ganesha.

[15]Keraf, A. Sonny. (1998). Etika Bisnis: Tuntutan dan Relevansinya. Yogyakarta: Kanisius.

[16]Loeb, Stephen E. \& Joanne, R. (1992). Accounting Ethics and Education: A Response. Journal of Bussiness Ethics.

[17]Ludigdo \& Tikollah. (2006). Pengaruh Kecerdasan Intelektual, Kecerdasan Emosional, dan Kecerdasan Spritual Terhadap sikap Etis Mahasiswa Akuntansi. Jurnal Bisnis. 
[18]Martadi, I. F., \& Suranta, S. (2006). Presepsi Akuntansi,Mahasiswa Akuntans, dan Karyawan Bagian Akuntansi Dipandang Dari Segi Gender Terhadap Etika Bisnis dan Etika Profesi. Simposium Nasional Akuntansi.

[19]Maulina, D. R. (2011). Persepsi Mahasiswa Akuntansi Terhadap Muatan Etika Bisnis dan Profesi Dalam Kurikulum Akuntansi. Jember: Perguruan tinggi Jember.

[20]Mubarok, A., Mahben, \& Jalil. (2010). Persepsi Mahasiswa Fakultas Ekonomi Pancasakti Tegal Yang Belum Mempunyai Pengalaman Kerja dan Yang Sudah Mempunyai Pengalaman Kerja Terhadap Etika Bisnis. Jurnal Cermin, Perguruan tinggi Pancasakti Tegal.

[21]Muchamad, N. (2006, juni 17). Produsen HIT Dilaporkan ke Polisi. Retrieved maret 10, 2016,fromtempo.co:https://m.tempo.co/read/news /2006/06/17/05779031/produsen-hi dilaporkanke-polisi

[22]Phillips, J.J. (1991). Handbook of training evaluation and measurement methods. Houson: Gulf Publishing Company.

[23]Prabowo, A. A., \& Haris, A. (2006, agustus 10). Kasus Perselisihan PT KAI Dibawa ke BPK. Retrieved 3 10, 2016, from Liputan6: http://www.liputan6.com/read/127216/kasusperselisihan-pt-kai-dibawa-ke-bpk

[24]Pratomowati, R. F. (2012). Peran Pendidikan Bisnis Terhadap Persepsi Etika. Semarang: Fakultas Ekonomika dan Bisnis Perguruan tinggi Diponegoro Semarang.

[25]Preble, J.F., \& Reichel, A. (1998). Attitude toward business ethics of future managers in the USA and Isreal . Journal of Business Ethics.

[26]Presiden Republik Indonesia. BIBLIOGRAPHY (1961). Retrieved from Undang-Undang Republik Indonesia Nomer 22 Tahun 1961 tentang Perguruan Tinggi: http://hukum.unsrat.ac.id/uu/uu_22_1961.htm

[27]Sari, L. P. (2012). Pengaruh Muatan Etika dalam Pendidikan Akuntansi Terhadap Persepsi Etika Mahasiswa. Jurnal Akuntansi Multiparadigma JAMAL, 334-501.
[28]Silanont, S. P. (2012). Business Ethics Perception of Thai Workforce: A Study of Age, Gender, Education, Management Experience and Ethics Training. School of Business and Technology of Webster University.

[29]Simanjuntak, I. I., \& Sinarti. (2013). Presepsi Mahasiswa Akuntansi dan Alumni Program Studi Akuntansi Politeknik Negeri Batam yang Telah Bekerja Terhadap Etika Bisnis. Batam: Politeknik Negeri Batam.

[30]Slameto. (2010). Belajar dan Faktor-Faktor yang Mempengaruhinya. Jakarta: Rineka Cipta.

[31]Svanberg, J. (2013). The Perception of Employees on Business Ethics In An Organization. Journal of Business Ethics and Corporate Social Responsibility.

[32]Utami, W. (2005). Etika Dan Pengembangan Pengajaran Akuntansi. BULLETIN penelitian. No08, hal 1-12.

[33] Vincent. (1997). Manajemen Bisnis Total dalam Era Globalisasi. Jakarta: Gramedia.

[34]Yosephus, S. (2010). Etika Bisnis: Pendekatan Filsafat Moral terhadap Perilaku Pembisnis Kontemporer. Jakarta: Yayasan Pustaka Obor. 